\title{
BOTE sign in molluscum contagiosum
}

\author{
Abheek Sil, ${ }^{1}$ Dibyendu Bikash Bhanja, ${ }^{1}$ Atanu Chandra ํㅏ, ${ }^{2}$ Surajit Kumar Biswas ${ }^{1}$
}

'Dermatology, Venereology, Leprosy, RG Kar Medical College and Hospital, Kolkata, West Bengal, India

${ }^{2}$ Internal Medicine, RG Kar Medical College and Hospital, Kolkata, West Bengal, India

\section{Correspondence to} Dr Atanu Chandra; chandraatanu123@gmail.com

Accepted 2 September 2020

Check for updates

(c) BMJ Publishing Group Limited 2020. No commercial re-use. See rights and permissions. Published by BMJ.

To cite: Sil A, Bhanja DB, Chandra $\mathrm{A}$, et al. BMJ Case Rep 2020;13:e239142. doi:10.1136/bcr-2020239142

\section{DESCRIPTION}

A 26-year-old immunocompetent man presented to the dermatology out-patient department seeking opinion regarding multiple reddish cutaneous eruptions over trunk and abdomen for the past few weeks. He was particularly distressed by a solitary bump near the umbilicus, which he claimed was painful. He had self-medicated with paracetamol tablets (500 mg two times per day) for a few days without any lesional improvement. He denied any other history of intake of oral/topical medication (allopathic or alternative) for his symptoms. Relevant medical history was notable for early-onset atopic dermatitis, which had been in remission since puberty. Cutaneous examination revealed multiple discrete, mildly tender, pink-red coloured, shiny, dome-shaped, umbilicated papules (ranging from $3-8 \mathrm{~mm}$ in diameter) with a surrounding intense erythematous halo distributed over the trunk and proximal upper extremities; some lesions had focal erosions and crusting (figure 1). The clinical impression of molluscum contagiosum was further reaffirmed by typical dermoscopic findings of roundish white-to-yellow structures with peripheral crown and dotted vessels. Giemsa stained smear showing multiple oval to round basophilic bodies with homogeneous appearance (Henderson Patterson bodies) confirmed our diagnosis as molluscum contagiosum. Secondary bacterial infection was ruled out as superficial swab failed to show any aerobic bacterial growth. Routine laboratory investigation including serology for HIV, viral hepatitis and syphilis was unremarkable. The patient was adequately counselled about the self-resolving nature of the condition, especially in the background of the obvious inflammatory response. The lesion had resolved on subsequent follow-up after 3 weeks. This spontaneous resolution of molluscum contagiosum lesions, heralded by a lesional inflammatory response, has been coined as the beginning of the end (BOTE) sign.

Molluscum contagiosum is a common skin infection caused by the molluscipox virus. Although, the course of the infection often includes tender, crusted, erythematous lesions that prompt suspicion and often result in empirical treatment for secondary bacterial infection, pathogen-negative bacterial swab cultures refutes the role of bacterial superinfection. ${ }^{1}$ Cutaneous perilesional plasmacytoid dendritic cell infiltration has been correlated with molluscum resolution. ${ }^{2}$ Recently, the acronym 'BOTE' sign has been proposed to

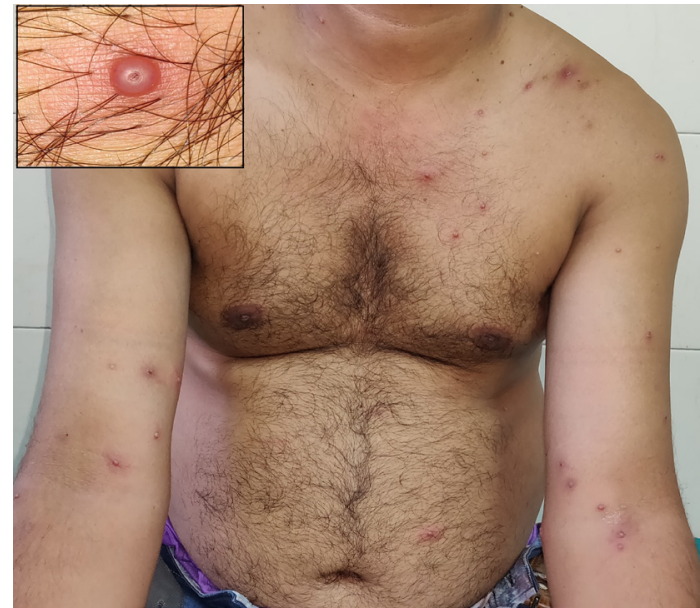

Figure 1 Multiple pink-red dome-shaped umbilicated papules with surrounding erythematous flare, focal erosion, and crusting overlying the trunk and proximal upper limb; (inset) magnified view of inflammed molluscum contagiosum demonstrating the typical beginning of the end sign.

help underscore the significance of the inflamed lesion as an expected variation in the evolution of immune response to the virus, rather than bacterial superinfection. ${ }^{3}$

We seek to highlight the BOTE sign as a predictor of impending resolution, rather than provoking concern.

\section{Patient's perspective}

I had experienced a painful reddish bump over my tummy for last few weeks. I have a previous history of atopic dermatitis. I was very anxious about the new rash. So, I sought an urgent dermatology consultation. After doing some tests, doctors told me that this is the beginning of the end and I was much relieved when my skin had almost healed over next few weeks. Now, I like the name, beginning of the end.

\section{Learning points}

The sign of inflammation in molluscum contagiosum represents a host response that often precedes resolution of the viral disease, rather than secondary bacterial superinfection.

- This phenomenon has been termed as the beginning of the end sign and this does not require additional antibacterial treatment. 
Contributors AS contributed to conception, initial drafting of the manuscript, critical revision of the content and final approval of the manuscript. DBB, AC and SKB contributed to patient management, conception, critical revision of content and final approval of the manuscript. All authors are in agreement to be accountable for all aspects of the work in ensuring that questions related to the accuracy or integrity of any part of the work are appropriately investigated and resolved.

Funding The authors have not declared a specific grant for this research from any funding agency in the public, commercial or not-for-profit sectors.

Competing interests None declared.

Patient consent for publication Obtained.

Provenance and peer review Not commissioned; externally peer reviewed.

\section{ORCID iD}

Atanu Chandra http://orcid.org/0000-0002-3809-8926

\section{REFERENCES}

1 Gross I, Ben Nachum N, Molho-Pessach V, et al. The molluscum contagiosum BOTE sign-Infected or inflamed? Pediatr Dermatol 2020;37:476-9.

2 Vermi W, Fisogni S, Salogni L, et al. Spontaneous regression of highly immunogenic Molluscum contagiosum virus (MCV)-induced skin lesions is associated with plasmacytoid dendritic cells and IFN-DC infiltration. I Invest Dermatol 2011;131:426-34

3 Butala N, Siegfried E, Weissler A. Molluscum BOTE sign: a predictor of imminent resolution. Pediatrics 2013;131:e1650-3.

Copyright 2020 BMJ Publishing Group. All rights reserved. For permission to reuse any of this content visit https://www.bmj.com/company/products-services/rights-and-licensing/permissions/

BMJ Case Report Fellows may re-use this article for personal use and teaching without any further permission.

Become a Fellow of BMJ Case Reports today and you can:

- Submit as many cases as you like

Enjoy fast sympathetic peer review and rapid publication of accepted articles

- Access all the published articles

Re-use any of the published material for personal use and teaching without further permission

Customer Service

If you have any further queries about your subscription, please contact our customer services team on +44 (0) 2071111105 or via email at support@bmj.com.

Visit casereports.bmj.com for more articles like this and to become a Fellow 